\title{
How did the ideas of Juri Lotman reach the West?
}

A memoir

During my first face-to-face meeting with the younger generation of the Tartu semiotics school during the Meeting of the International Association for Semiotic Studies in Dresden in 1999, Peeter Torop - now Lotman's successor in the chair of semiotics at Tartu University - asked me to write down my recollections about how I discovered Juri Mikhajlovich first two monographs on semiotic aspects of artistic texts $(1964,1970)$, and how I was able to bring these monographs to the United States and thereby to open them up for the world of Western learning. To this request I recklessly assented, not giving much thought to the difficulties inherent in this the task. The proposed memoir seemed so simple, and so wholly straightforward. Was it not a simple task of retelling something, which is an intimate part of my own personal experiences, my own recollections, my own intellectual biography? But, as I was to learn painfully when I sat down to prepare this paper, this was not at all the case. For what follows involves not just a piece of my lived life, but something which literally turned my scientific maturation on its ear, and was to become a vigorous compass for the direction of my further intellectual paths. So, as the Germans say: "Wer A sagt muss auch B sagen," here I am, trying to say B.

I was not entirely unprepared for my encounter with Lotman's work. But now the direction of my work, under the influence of Lotman's theoretical work, and that of his colleagues, B. A. Uspenskij, V. V. Ivanov, N. Toporov, and others, changed course in the direction of literary and cultural theory and especially of Lotmanian semiotics.

If I may be allowed to reflect on the most determining circumstances which have crucially influenced the development of my scientific literarylinguistic-poetic-semiotic views. I would name three guideposts terms of reference. They were the following.

That I entered literary studies from the angle of Slavistics, and especially from the viewpoint of a native Czech speaker. I had grown up in Prague during the 1920s and 1930s; and Prague was at that time a flourishing scholarly and artistic center, especially in the study of language in its broadest aspect beginning with empassioned concerns with the forms, functions, and 
styles of the Czech language. For in the so-called historical crown lands of Bohemia-Moravia-Silesia, the Czech language had, since the defeat of the Czech Protestants in 1620 by the Holy German Empire under the dominance of the Austrian Habsburg dynasty, been forced into a subordinate position relative to German because of the Germanization policies of the Habsburgs, and the expulsion and execution of large numbers of Czech nobles and intellectuals. Consequently, by the early nineteenth century, Czech had basically ceased to be spoken among the upper and intellectual levels of the population in the Czech lands who spoke and wrote in German and sometimes in Latin, the latter especially for scholarly writing, creating thus a situation not unlike that in Estonia during the same time-span. The Czech language had found its shelter primarily among the peasants and the urban working classes. Consequently, when, at the beginning of the nineteenth century, the leaders of the Czech Revival movement (národní obrození) endeavored to restore Czech culture, they turned their attention first to the Czech language in this attempt to restore its use by establishing new norms for it and it is no wonder then that the Czechs became known as the nation of philologists. This linguistic disposition has been an important feature of Czech culture ever since the strivings of the Czech Revivalists to breathe new life into the Czech language, and one consequence of this historical fact was the emergence of two strikingly independent parallel dialects of Czech, written and spoken Czech, dialects which as the bifurcated system of modern Greek, create a radical differentiation between these two aspects if the language system. Questions as to where one or the other idiom was permissible, and where its use was proscribed, abounded especially since the end of the nineteenth century, when some writers used a mingling of the two grammatical and phonetic systems in neighboring positions in one and the same text as foregrounding devices. Such techniques became a device of great importance in the texts of the literary avantgarde of the second and third decades of the last century. In these decades, which coincided with those in which I was growing to maturity and young adulthood in Prague, such questions became acute creating a situation in which both linguists and writers cooperated in lively fashion; and this was also the situation in other European countries, notably in Russia, where the Moscow Linguistic Circle, in many ways a precursor of the Prague Linguistic Circle, joined in the work of the avantgarde poets in searching for new ways of expressing the essence of the nature of literature (literaturnost'). The literary-linguistic organization "The Society for the Study of Poetic Language (OPOJAZ - obscestvo dlja izucenija poeticeskogo jazyka), was launched in St. Petersburg in 1915 as the basis for such collaboration. For traditional linguists of the time, issues of poetics had been strictly out of bounds, a delimitation which was almost as strongly felt by the users of poetic speech, the writers of literary works. But by the second decade of the twentieth century it had become quite as acceptable, indeed tempting, for a linguist to be immersed in questions of poetic language, as for a poet to be absorbed by technical issues in linguistics. 
That the Russian situation in the first three decades of the past century was very similar to that in Czechoslovakia during the 1920s and 1930s is epitomized by the fact that many Russian poets, especially Vladimir Majakovski and Velemir Khlebnikov, showed great interest in the work of the Moscow Linguistic Circle and, conversely, linguists like Roman Jakobson were bound by bonds of friendship with the poets of the time, and not only showed interest, but also participated, in the work of the OPOJAZ. Roman Jakobson, as is well known, even wrote himself futurist (Baum) poetry under the nom de plume of Aljagrov.

In 1920 an event of great import for Czech linguistics and poetics was the relocation of Roman Jakobson to Prague, first as press attache of the Soviet embassy; but after a few years as a permanent settler; and he lived in Prague and Brno until he was forced to flee from the German troops that occupied Bohemia and Moravia in 1939. The young Jakobson was full of enthusiasm for the new functional linguistics, and he soon took up contact with Czech linguists and poets; and in 1926, together with the Czech linguist Vilem Mathesius and others, he co-founded the Prague Linguistic Circle (Prazsky lingvisticky krouzek), whose Vice-President he was from 1927 until his escape in 1939. During his stay in Prague and Brno (he was appointed professor of Slavistics at the Brno University (later, Masaryk University). In Prague, he broadly extended the field of linguistics to the exploration of functional language in its relation to other domains, especially poetics. It was not surprising then that he soon established relations of close friendship not only with Czech linguists (Vilem Mathesius and Bohuslav Havranek) but also with the professor of aesthetics at Charles University Jan Mukarovsky and leading Czech and Slovak poets and personalities in other fields of literature (V. Vancura, V. Nezval, J. Seifert, L. Novomesky, and the theater producers and actors Voskovec and Werich). With his fellow Russian emigre Petr Bogatyrev, he studied the interaction between language and folk art in the broad field of semiotics; carried on a spirited battle against the representatives of conservative, puristic trends in Czech linguistics. His activities, together with the other collaborators in the Prague Linguistic Circle, were to have a powerful influence on European linguistics and literature; and in his famous essay on Czech verse and versification (O cheshkom stihe, 1923, repr. 1969), he demonstrated convincingly not only the fallacy of accentual metrics for Czech versification as elaborated by the Josef Kral school, but also demonstrated compellingly that the versification system of any language can never been examined without attending to the complex relationship between a given language system and its prosody (cf. Winner 1969: vii).

This was the artistic and scientific atmosphere of my youth and early adulthood. And when I arrived at Harvard on a Refugee Fellowship in 1939, I chose as my field of specialization that of Slavistics, which elicited considerable irritation by the then leading American Slavist, the late Samuel Hazard Cross, a man of unimaginative and pedestrian scholarship, who saw in this option only the sloth of a young man who knew at least one Slavic language 
"anyhow," and, indeed, not one acquired by studious occupation with grammar books, but imbibed with the mother's milk. Needless to say, Professor Cross was frequently "cross" with his young student, and tried to hinder his academic maturation. Yet, I persisted; and when, after suspending my studies for service in the Second World War, I returned to Slavic studies in 1945, it was not to Harvard (for Cross had died and there were no Slavic studies then at that university) but at Columbia University under the benevolent eye of the late Ernest J. Simmons who told me at our first encounter that I simply must meet the new Professor from my own native Czechoslovakia, occupant the holder of the chair in linguistics and Czechoslovak studies. I rang the bell to Professor Jakobson's small and frugal apartment. The door opened and a man whose reddish hair stood up straight and whose strabistic eyes glared at me with some consternation. But the eyes and the entire face changed expression radically when I addressed him in Czech and explained my mission. I was immediately invited in, and from then on, this apartment was that of my teacher and, later, close friend. It was not only our common fascination with Czech and Russian literature, especially the poetry of these two languages, but also my growing interest in poetic theory, especially that of the Prague Circle, which fastened our affinity and cameraderie which was to last until his death in 1982.

I stated at the beginning of this essay that it was three points of reference which prepared me for my encounter with Juri Mikhajlovic Lotman, first with his works in 1966. And then with him personally in 1973. Looking back at my scientific career from the outlook of a mid-octogenerian, it is difficult not to see these three points of contact as a persistent gradation, where each new encounter, each new revelation, unearthes another piece of what seems like a straight line of extension, continually moving from my childhood in Prague to the rencontre with the Moscow-Tartu school. This is so different from the curriculum vitae of the "average" "Western" literary scholar, historian, and student of culture.

I feel compelled, at this juncture, to add to these experience a third rencontre that with the person who, for just sixty years this year, has been my closest collaborator and scientific confederate, my wife Irene Portis-Winner now, like me, a retired professor but one not of literature but a specialist in cultural anthropology. From her indefatigable boundary-crossings from culture to culture and from discipline to discipline, and especially from her fascination with the pertinence of her varied areas of research to semiotics of culture; from the fact that I was able to accompany her on all of her many research trips in the "field" and my ability to be an active part of the fieldwork process, have powerfully enriched, broadened, focused, and buttressed my approach to my own field, in its theories and application to actual literary texts.

For all these propitious encounters and turns not only in my scientific but also my personal life that attended me through the many difficult shoals of life, I had to negotiate in my long career, for all these, I am ever thankful. 
Now to the denouement of the narrative of this part of my life.

It was on a crisp mid-winter morning in Moscow of the year 1967, one of those splendid cloudless, crisp almost windless winter days for which Moscow is known, that I mounted the snow-covered stairs of the Lenin Library (now the Russian State Library [RGB]), and went to my usual seat in the so-called professors' room. My books were already on my desk waiting for me to begin reading for my research which was, I anticipated, to lead to a book on the prose of the Russian writer Ivan Bunin. For I had received a research grant that would allow me to do research in the holdings of the Lenin Library and the Central State Archives for Literature (CGALI). After a few hours of absolute silence, with all visitors bent over their desks and busily taking notes, a bell sounded for the so-called "Hygienic Intermission" (Sanitarnyj pereryvok); everyone rose from their seats and went out into the hall to perambulate or to drink some tea or coffee in the near-by cafeteria, while the windows of the reading room were thrown wide open, allowing the clear sub-zero air from the outside to enter the room and to freshen the air which had grown somewhat stuffy with the clean and fresh air from outside.

The tables in the reading room were placed in close proximity, and each researcher occupied his or her own table. A young man was sitting at the neighbouring table, and what he was reading peaked my interest. As far as I could see from afar, the books title dealt with poetics and, more specifically with structural poetics. When all the readers were leaving the room, I sneaked a glance at the book which had aroused my curiosity. The very title elicited my compelling interest. It was called Lectures in Structural Poetics (Lekcii po struktural'noj poetike) and the author was Juri Mikhajlovic Lotman. I leafed briefly through its pages, and realized that my curiosity was justified. Here was, so it seemed, an attempt to treat literature not as an isolated fact of life, but as closely linked to other phenomena of a culture. I had time only to glance at the firs sentence of the introduction which stated:

The contemporary development of scientific thought is increasingly characterized by a tendency to look not at separate and isolated phenomena of life, but at broad units, and to see how each of these even seemingly most simple events of reality turn out, at closer inspection, to be a structure consisting of even smaller elements and itself is but a part of a more complex configuration. With this is connected the deeply dialectical concept that for the understanding of a phenomenon it is insufficient to study it in its isolated nature, one must also determine its place in the system. (Lotman 1968: 1; italics supplied)

So here I was confronted with the profound structural principle that had been so inspiringly developed during the twenties and thirties in Prague, especially by Jakobson and Mukařovský, and that was continued by the later after the War in his projected "system of systems". Applied to the language sciences, linguistics and literature, this meant that in the examination of a literary text 
the close reading of the American New Critics of the 1930s and the French structuralists of the 1960s was no longer adequate. For each text in the verbal arts not only consisted of elements on lower levels, but was itself part and parcel of a broader system, encompassing not only the system of a national literature, or a subsection of its history, but the structure of the language in which the text is written, and its relation to even broader levels, that of the totality of culture, for example.

That such theories were entertained by the Prague circle, I knew, but I had not encountered such broad thoughts elsewhere. And here I had seemingly stumbled over a true revelation. When the "sanitary intermission" was over, and the windows closed again, I engaged my neighbour who was reading the book in a conversation and we left the room to walk up and down the hallways and corridors to talk. I learned then that there was a school that interested itself in semiotics and structuralism in language and literature, and I also obtained the names of the major figures in this movement in the then Soviet Union of which we in the "West" had been profoundly ignorant.

When I attempted to order another copy of Lotman's lectures to read it at greater leisure, I was told that there was only one copy of it in the library, and that I would have to wait my turn, and that there were several other readers whose order for this volume had preceded mine. I learned then, with a great sense of consternation that this, seemingly so important, study had been published in the minuscule edition of 500 copies. While awaiting my turn for the Lotman book I scoured the Moscow bookstores. But it was all in vein. While all the booksellers whom I approached were acquainted with the name and reputation of Juri Lotman, the book was sold out with no chance in of gaining access to a stray copy.

When, after several weeks, it was my turn at the library, and I at long last was able to read Lotman's book, I almost drank it in, I was convinced that I had found a true treasure trove, and that it was my absolute duty to bring at least a photo copy to the United States, in the hopes of reprinting the monograph in the series Brown University Slavic Reprints, of which I had just become the editor-in-chief. But even this took an enormous amount of time and effort; for not only were the Lotmanian theses not popular with the Soviet aparachiki, I had also to deal with the Gogolesque phenomenon of the lower Russian bureaucracy, which feared anything out of the ordinary and placed ever more obstacle into my path.

But I succeeded and was able to bring the photocopied book to the United States, where it was published as a reprint a few months later with my introduction in which I attempted to lay out for my readers a little bit of the history and essence of the Lotman Tartu-Moscow school. And three years later, and three years wiser, I was able to obtain Lotman's next monograph, on a return visit to Moscow, and publish it also as a reprint, with an explanatory introductory essay (Lotman 1971; Winner 1971).

The door was now open, and my reprint was followed shortly by a series of translations by the American Slavists Henryk Baran (1976) and the many 
reprints and translation by the Slavists at the University of Michigan under the editorship of Ladislav Matejka, Krystyna Pomorska, and others (e.g., Matejka, Pomorska 1971).

In conclusion I reflect upon and summarize some dominant points in our discussion of Lotman's contribution and his heritage which encompasses his revolutionary poetics, as contrasted to approaches to poetics in the West. As I have shown, the Prague school, which rejected the separation of poetics and linguistics and a synchronically guided study, and espoused the universal whether dominant or not, and also Russian formalism, contributed to Lotman's thinking. But these were primarily, though important, points of departure for Lotman in his dialogue with the masters of the past and present, energized by his own boundless creativity and foresight that pointed to the broadest future directions for the study of human culture in all its dimensions.

Meanwhile poetics in the west took its fitful paths, never severing fully its ties to Saussurean cognitive static structuralism which did not encompass aesthetics or subtleties of meaning, nor context and point of view. Thus it was not out of tune with positivistic or hermeneutic positions (for example the new critics in some American universities). Eventually this lead to what we might term the reductio ad absurdum where comparativism, and meaning were essential abandoned for deconstruction fathered by Derrida and evolving into the even more barren postmodernism. Meaning which had not been captured except in the Saussurean arbitrary cognitive mode becomes entirely subjective to the reader and unrelated to form or to context or the subtleties of aesthetic interpretations. Point of view from the inner and outer approach, history and context were all ignored for a form of sterile relativism abandoning all thought of any unifying underlying principles in human culture. Franz Boas's famous statement that we must only compare comparatives was dissolved, since indeed no text is comparable. Western scholarship had thus reached the point of no return which is not to say that the deconstructionist at least felt that they discovered some underlying assumptions that were buried, thus the search termed the hermeneutics of suspicion. But it need not follow that we must assume essentially meaninglessness on the obvious level to find deep hidden assumptions which according to the deconstructionists may not necessarily indicate any common qualities in texts that may be compared. On the contrary meaning exists on various levels and my be subtle or ambiguous but it always there to be interpreted.

To turn back to the Prague school, its rebellion rebellion against the Saussurean heritage was a milestone. The possibilities of a science of signs, foreseen by Saussure but not developed, was left to the Prague school. Bogatyrev was the first to apply a semiotic analysis to the nonverbal structure of peasant costumes. Most importantly, Jakobson rejected Saussure's exclusively arbitrary sign, and iconicity and the object were again recovered.

The great contribution of the Moscow-Tartu school was the development of a semiotics of culture and the position that underlying values, foreseen by Mukařovský, shaped culture. Lotman found that Prirogine's work in the exact 
sciences and biology had significance for all scientific thinking because they "tackled the problem of chance in the sciences and [...] demonstrated the function of random phenomena in the general dynamics of the world" (Lotman 1990: 230). Thus the science of signs was dynamic and applied to the widest phenomena, to all signs verbal and nonverbal and body movements, and all the arts and particularly cinema (Eisenstein and the theory of montage), to everyday behavior and certainly history and context including physical and biological phenomena, and indeed to perception of time and space and the universe. In the later Moscow-Tartu school the signifier and signified were no longer split but in Peircean tradition the sign was a whole that pointed to an object and was interpreted through another sign, the interpretant, in an endless series and thus an infant regress. For Peirce interrelation of all phenomena meant continuity. Peirce was probably not read by Lotman since Peirce was published late and not translated, but there were strong intertexualities.

Clearly Lotman saw that human behavior and culture was continually interrelated but did not necessarily always change gradually, and thus his theory of cultural explosion and his understanding of the relativity of chaos, which for one culture may be order, but looking beyond the culture borders another culture might appear as chaos although to the culture bearers of that culture it is seen again as order. The interpenetrating character of all cultures, the dynamics of permeability of borders were essential assumptions.

To be so farsighted and free from conventional scholarship one must be courageous and imaginative, as was Lotman, looking beyond official knowledge to ask questions which do not already determine the answer. Thus Lotman became and continues to be an inspiration for more far-reaching research and creativity for writers, artists, musicians, anthropologists, ecologists, biologists, philosophers, linguists, psychologists and in fact for scholars and artists in all fields of inquiry.

The stage has thus been set for an immense program which will surely spread world-wide, helping us to explore and understand cultural variations and underlying similarities, and polysemic signs and their transformations of meaning, the pervasive norm-breaking and norm-perverting aesthetic function. It is useless to deconstruct the sign into meaningless empty signifiers. The sign can be variously interpreted but not infinitely, and always depends on point of view, culture values, history etc. Its meaning can be transformed but never obliterated. Levi-Strauss saw this in his mammoth study of transformation of myths, depending on all these factors and particularly ecological environment. A few decades ago Margaret Mead wrote foresightedly that the issue is differences and similarities in cultures.

When my wife and I met Lotman for the last time in a Munich hospital, he was already very ill. He enchanted us with his graciousness and old world ways. His charm and warmth were as sincere as were his searching works which laid out the farthest perspective for continuing, deepening and thoughtprovoking inquiries into the world of semiotics of culture. Lotman understood 
interdisciplinary studies in the deepest sense, that is as the possibility of communication embedded in the most various forms, encompassing complex and continuous interrelations of all reality, the physical and biological world, even the universe, and human creativity, the basis for culture. All of which does not omit the ever-changing forms of order and chaos.

\section{References}

Baran, Henryk (ed.) 1976. Semiotics and Structuralism: Readings from the Soviet Union. (Translated by William Mandel, Henryk Baran, and A. J. Hollander.) White Plains: International Arts and Sciences Press.

Eimermacher, Karl; Shishkoff, Serge 1977. Subject Bibliography of Soviet Semiotics: The Moscow-Tartu School. Ann Arbor: Michigan Slavic Publications.

Jakobson, Roman 1969 [1923]. O cheshkom stihe; preimushchestvenno v sopostavlenii s russkim. (Brown University Slavic Reprints 6.) Providence: Brown University Press, 17-19.

Lotman, Juri Mikhajlovic 1968 [1964]. Lekcii po struktural'noj poètike: Vvedenie, teoriya stiha. [Trudy po znakovym sistemam - Sign Systems Studies 1.] (Brown University Slavic Reprints 5.) Providence: Brown University Press.

- 1971 [1970]. Struktura hudozhestvennogo teksta. (Brown University Slavic Reprints 9.) Providence: Brown University Press.

- 1990. Universe of the Mind: A Semiotic Theory of Culture. Bloomington: Indiana University Press.

Matejka, Ladislav; Pomorska, Krystyna (eds.) 1971. Readings in Russian Poetics: Formalist and Structuralist Views. Cambridge: MIT Press.

Winner, Thomas G. 1968. Introduction. In: Lotman 1968: vii-X.

- 1971. Introduction. In: Lotman 1971: vii-x.

Thomas G. Winner ${ }^{l}$

1 Author's address: Thomas G. Winner, 986 Memorial Drive, Apartment 404, Cambridge, Massachusetts 02138 USA; e-mail: tgipwinner@mediaone.net. 